\section{Olympic tears}

Published at www.cmaj.ca on Jan. 21

Roughly 12000 people were expected to carry the torch during the 100-day Olympic Torch Relay, which was scheduled to pass through more than 1000 communities, and cover 45000 kilometres, before arriving in Vancouver, British Columbia, for the opening ceremonies of the 2010 Winter Olympics on Feb. 12.

I always loved watching the Olympics on television. The opening ceremonies were so elaborate; I would watch them in their entirety. I loved seeing the Olympic cauldron lit by some famous Olympian.

So when I saw ads looking for Olympic torchbearers last winter, I applied through Coca-Cola Canada, one of the official sponsors. I sent in what amounted to a CV. It was followed by a math question. I even solved it myself, although I had not needed to solve a math question since my premed year at McGill University in Montréal, Quebec. A few minutes later, I solved it again, and got the same answer, so I sent in my solution. It was right.

I also had to write an essay on two topics: environmental responsibility and active living. One of my daughters, who is a good writer, said she would help me, but that she would not write it for me. I knew I had done something right in raising her. Help me she did and the essay was eventually submitted, along with all of the other parts of my application.

An email reply came months later, on Canada Day, informing me that my permission was needed for the RCMP to investigate me - the final step in the process.

One month later, while at work in my office, I got a call from the torchbearer committee. I had been chosen to be a torchbearer for the 2010 Vancouver Olympics.

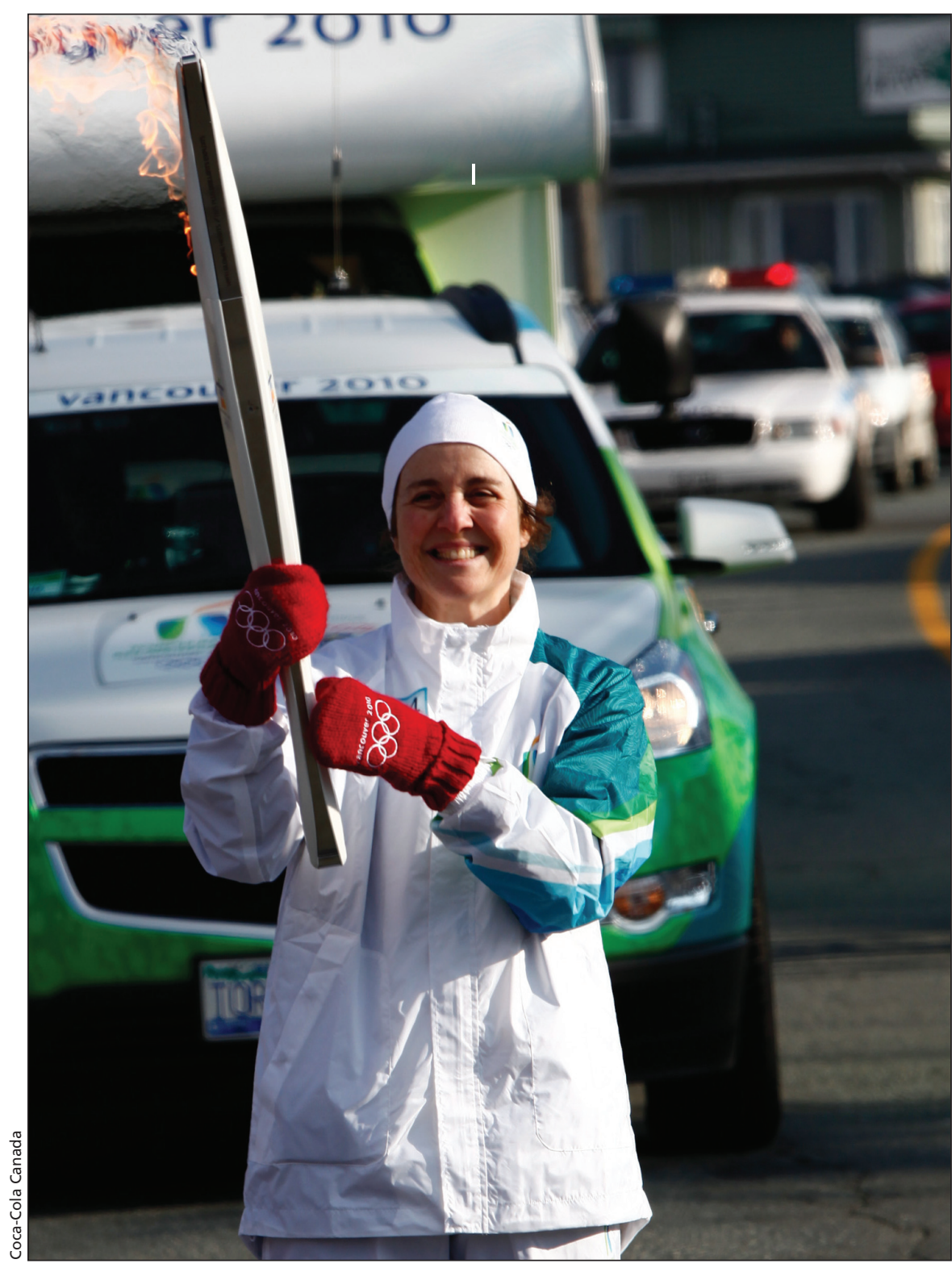

Dr. Aline Levi carries the flame during the 100-day Olympic Torch Relay in Granby, Quebec. She trained by running short distances with a full water bottle held high, simulating a torch.

My kids simply could not believe that their mom was going to do something so cool.

It certainly gave me something to look forward to in the long winter. And at 49 years of age, I thought it was a perfect way to end my 40s, and hit my 50s "running," symbolically that is.
This was how I would greet my fifth decade of life: Olympic torch lit, smiling and waving.

My torch run was scheduled for Dec. 6, 2009, day 38 of the Olympic torch relay.

My parents opted to delay their planned trip to Florida, not wanting to 
miss the moment. As it neared, I got very excited.

I even researched the history of the torch relay. It began in 1936 at the Berlin Olympics, as a means of showcasing Nazi Germany to the world. Boycotts had been planned for those Games but they fell through and events were held before ranks of Nazi elite, who took credit for how well the Germans performed. I learned that the Vancouver Holocaust Education Centre has both onsite and online exhibits on the topic.

And I thought how proud I was to be a torchbearer. A Canadian Jewish physician, born 15 years after the end of World War II, married to a son of Holocaust survivors, I would be holding the torch high, showcasing Canadian values of equality and sportsmanship to the world.

What a way of turning the tables on the 1936 Berlin Games!

I could not wait to run in Granby, Quebec.

As I am a swimmer, not a runner, I trained by running short distances with a full water bottle held high, simulating a torch. I did not want to be tired or out of breath when I actually carried the Olympic flame.

On the weekend of my run, my entire family arrived from across Canada. My eldest daughter and her fiancé came from Ottawa, Ontario, taking a break from law school, cameras in hand. My second daughter put her essays at the University of Toronto in Ontario on hold. My sons, husband and parents, as well as my youngest nephew, all trekked to Granby.

The excitement escalated as I met the other torchbearers and members of the organizing committee.

The torches were handed out - one metre tall, sleek, inspired by snow drifts on mountains, made and individually signed by Bombardier engineers, and each filled with propane.

We torchbearers were briefed and whisked away on a minibus.

My family was instructed where to line the route to get the best view of the first torchbearer - me.

I arrived at my start site, a crowd of people already present and ready to take photographs with me. I could not see my kids.

My torch was lit by a lantern from Olympia, Greece, where the Olympic flame was lit from the rays of the sun and eventually brought to Canada.

I ran proudly with the beautiful torch, escorted by the RCMP and official Olympic committee organizers. I ran about 500 metres down the main street of Granby, as people waved and cheered.

I waved back with my official red Olympic mittens, complete with maple leaf.

At the end of the road, I lit the next torchbearer's torch with mine, hearing the click of camera after camera.

My run was over. I was whisked away by the waiting minibus. I waved to the crowds.

And then I saw my daughters running alongside the bus, waving and crying.
They had been sent to another part of the relay route and had missed my entire run. None of my 11 family members who'd come with me had seen my torch run.

We had not a single photo, no video.

We laughed and cried. My mom in particular did not think it was funny, which really made me laugh.

I had run the relay bursting with Canadian pride. But none of them were there to share it.

I later contacted the organizers and was able to get two photos of me running with a lit torch. After much discussion, CTV News located a video of my run. It's now on YouTube, so my family can see it anytime.

And I know I really did it. My Olympic torch stands on a table in my home, with the soot of the Olympic flame purposely left on, although I really need no proof of this moment, which is carved in our memories. It will always be one of my family's great stories. - Aline Levi MD, Granby, Que.

DOI:10.1503/cmaj.109-3162

CMAJ invites contributions to "Dispatch from the medical front," in which physicians and other health care providers offer eyewitness glimpses of medical frontiers, whether defined by location or intervention. Submissions, which must run a maximum 700 words, should be forwarded to:wayne.kondro@cmaj.ca 